\title{
Faculty Engagement in Cultural Mentoring as Instructors of Short-Term Study Abroad Courses
}

\author{
Elizabeth Niehaus \\ Jillian Reading \\ Matthew J. Nelson \\ Ashley Wegener \\ Ann Arthur \\ University of Nebraska, Lincoln
}

\begin{abstract}
:
The purpose of this study was to explore what cultural mentoring looks like in practice in shortterm study abroad courses, how frequently instructors engage in cultural mentoring, and what demographic and background variables might predict the extent to which faculty members engage in cultural mentoring. Using data from a survey of 473 faculty members from 72 U.S. colleges and universities who had recently taught short-term study abroad courses, we identified four types of cultural mentoring behaviours: Expectation Setting, Explaining the Host Culture, Exploring Self in Culture, and Facilitating Connections. We also identified key predictors of the frequency with which participants engaged in cultural mentoring, including rank, race/ethnicity, and discipline.
\end{abstract}

In 2005, the U.S. Congressionally-appointed Commission on the Abraham Lincoln Study Abroad Fellowship Program set a goal of sending one million U.S. students on study abroad experiences annually, stating that "engagement of American undergraduates with the world around them is vital to the nation's well-being” (p. v). Although still far short of the Lincoln Commission's goal, since 2005 the number of U.S. college students participating in study abroad experiences has increased by nearly 50 percent (Institute of International Education [IIE], 2015). Much of this increase comes from the rise of short-term abroad experiences (defined by IIE as eight weeks or fewer), which now outnumber traditional semester- or year-long study abroad programs (Gutiérrez, Auerbach, \& Bhandari, 2009; Obst, Bhandar, \& Witherell, 2007).

One of the main rationales for promoting study abroad in the U.S. is the development of intercultural competence, an increasingly valued skill in today's global society. Approximately $79 \%$ of all American Association of Colleges \& Universities (AACU) institutions consider intercultural skills a learning outcome for all students (AACU, 2011). Study abroad experiences can provide students the opportunity to develop their intercultural competence by immersing themselves in new cultures, learning from others of diverse backgrounds, and developing a set of skills for an increasingly interconnected world (Anderson, Lawton, Rexeisen, \& Hubbard, 2006; Keese \& O'Brien, 2011). 
Although study abroad can promote intercultural competence, simply going abroad is not necessarily sufficient to do so (Bennet, 2008; Jackson, 2008); the research on whether short-term study abroad programs can facilitate intercultural competence development is mixed. Some studies have found that short-term study abroad can lead to positive gains in intercultural competence (e.g., Anderson et al., 2006; Chieffo \& Griffiths, 2004), while others have found either no gains from short-term study abroad (Medina-López-Portillo, 2004), or that longer-term programs lead to significantly greater gains (Kehl \& Morris, 2007).

One way faculty members who teach short-term study abroad courses may be able to maximize the potential of these experiences to facilitate students' intercultural learning is through focusing on cultural mentoring. Paige and Goode (2009) defined cultural mentoring as "the role of international professionals in facilitating the development of intercultural competence among their students" ( $p$. 333). Stier (2003) identified mentoring as one of the four main roles of international educators and highlighted the importance of mentoring students and serving as a role model and discussion partner. By acting as what other researchers call a cultural development guide (Marx \& Moss, 2011), cultural mentors can assist students through their growth in intercultural competence.

Despite the importance of cultural mentoring, little is known about if and how faculty members who teach short-term study abroad engage in cultural mentoring. The purpose of this study was to explore what cultural mentoring looks like in practice in short-term study abroad courses, how frequently instructors engage in cultural mentoring, and what demographic and background variables might predict the extent to which faculty members engage in cultural mentoring.

\section{Theoretical Framework and Review of the Literature}

The role of faculty members as cultural mentors in short-term study abroad is grounded in theories of intercultural development. The assumption that studying abroad can facilitate intercultural development is based in Allport's (1954) contact hypothesis, which posited that contact between different groups of people could lead to greater understanding of group differences. Although research suggests intergroup contact can have beneficial outcomes (e.g., Pettigrew \& Tropp, 2005), simply going abroad does not necessarily lead to increased intercultural competence (Bennet, 2008; Jackson, 2008; Vande Berg, Paige, \& Lou, 2012), in part due to the psychological challenges that often occur on study abroad programs. Stier (2003) called going abroad an emotional journey, citing feelings of loss, insecurity, and uncertainty experienced by those traveling abroad. Other research studies highlighted feelings of anxiety (Lucas, 2009), culture shock (Buffington, 2014), and the need for emotional support (Doyle et al., 2010). Not all students are able to successfully navigate the new cultural environment or manage the identity renegotiation process that may occur as a result of exposure to a different culture.

These challenges encountered in study abroad experiences are not in themselves a detriment. The disequilibrium experienced on a study abroad trip can lead to teachable moments to help students learn more deeply about the host culture as well as their own beliefs and values (Bennet, 2008; Buffington, 2014). These trigger events can be a catalyst for turning culture shock into cultural learning, providing the process is "well facilitated" (Bennet, 2008, p. 17). Having guidance for 
students as they experience these challenges then becomes an important part of the intercultural competence development process; cultural mentoring can provide this guidance.

\section{Cultural Mentoring in Education Abroad}

According to Paige and Vande Berg (2012), cultural mentoring includes "engaging learners in ongoing discourse about their experiences, helping them better understand the intercultural nature of those encounters, and providing them with feedback relevant to their level of intercultural development" (p. 53). Cultural mentoring helps students to become more culturally self-aware and suspend hasty judgments before responding to people and events (Vande Berg et al., 2012). Cultural mentoring, then, stands as the vehicle by which students are able to find meaning in their study abroad experiences and transfer the competencies gained from the experience into their interactions with others. In a review of relevant theoretical frameworks of intercultural competence, Paige and Goode (2009) identified a number of behaviors that may fall under the umbrella of "cultural mentoring":

- Pre-departure sessions addressing intercultural competence; examine student's expectations for the study abroad experience, themselves, and the host culture; allow students to discuss how their own individual identities (e.g., race, ability, gender, etc.) may be perceived by members of the host culture; and explore differences between the home and host culture;

- On-site reflection on cultural differences between the home and host culture;

- General discussions about culture, how to recognize dimensions of culture, and the process of adapting to a different culture;

- Discussions about students' own culture(s) and cultural assumptions;

- Providing specific information and challenging students' assumptions about the host culture;

- Structured "breaks" from deep cultural immersion, including time for students to interact with people from their own home cultural group;

- Giving students ideas about how to explore the host culture;

- Providing advice about navigating cultural issues and practical matters (e.g., making a phone call, using public transportation, etc.) in the host culture; and/or

- Considering students' individual levels of intercultural sensitivity and adapting teaching and mentoring accordingly.

Additionally, Paige and Goode asserted that cultural mentors must pay attention to their own levels of intercultural competence and how this may influence their mentoring.

\section{The Need for Cultural Mentoring}

Research from around the world points to the need for cultural mentoring in international education. As Jackson (2008) found in a study of Chinese students studying in England, students do not always recognize the need to develop their intercultural competence. Participants in Jackson's 
study had inflated perceptions of their own intercultural sensitivity, perhaps impeding their growth. Other researchers have pointed to the detrimental effects of a lack of cultural mentoring and support in education abroad. Koskinen and Tossavainen (2004) found that Finnish nursing students on an exchange program in the United Kingdom had trouble finding cultural meaning in their experiences due to poorly facilitated orientation and re-entry programs. Doyle et al. (2010) similarly found one of the obstacles for New Zealand students studying abroad was a perceived lack of emotional support in a new cultural environment.

When cultural mentoring is present, research on study abroad generally has demonstrated its value in developing students' intercultural competence. In the Georgetown Consortium Project researchers found U.S. students studying abroad who met with a mentor to work on intercultural learning made greater gains in intercultural competence than those who did not (Vande Berg, Connor-Linton, \& Paige, 2009). Lou and Bosley (2012) found students who received facilitation through a mentor during study abroad advanced their intercultural competence nearly twice as much as students who guided themselves through the facilitation process. Each of these studies illustrates that cultural mentoring is a necessary part of the developmental process for students studying abroad, and that faculty members need to be ready to provide such support. All of these studies, however, focus on longer-term study abroad programs, and few provide details about what specifically was involved in the cultural mentoring in question.

\section{Faculty Members as Cultural Mentors}

Faculty members who teach short-term study abroad courses are well-positioned to serve as cultural mentors for students due to the intense nature of these courses and the high levels of faculty-student interactions that can take place during the time abroad. Yet, little is known about what faculty members are actually doing while teaching study abroad courses and how they might be engaging in cultural mentoring. In one of the few studies on faculty members who teach short-term study abroad courses, Goode (2008) found that faculty members rarely discussed their role in students' intercultural learning when describing the various dimensions of teaching abroad.

Although there is little research specifically on faculty members as cultural mentors in shortterm study abroad programs, there is a great deal of research pointing to the factors predicting which faculty members are more likely to engage in effective cultural mentoring than others. Faculty members' own intercultural competence may influence their ability to act as cultural mentors for students (Paige \& Goode, 2009), although as Schuerholz-Lehr (2007) found, intercultural capacity and prior international experience does not always "translate automatically into more globally inclusive teaching practices" (p. 199). Related to the idea of cultural mentoring or culturally engaged pedagogical practices, other research has shown that Faculty of Color are more likely than their White counterparts to place an emphasis on incorporating diversity-related content into their courses (Mayhew \& Grunwald, 2006); similarly, women are more likely than men to focus on diversity in their teaching (Mayhew \& Grunwald, 2006; Nelson Laird, 2011) and to engage in active instructional practices (Nelson Laird, Garver, \& Niskodé-Dossett, 2011).

Discipline may be another factor that contributes to the extent to which faculty members engage in cultural mentoring. Research on approaches to teaching has found that instructors in "hard" disciplines (generally science, technology, engineering, and mathematics [STEM] fields) tend 
to approach teaching in substantively different ways than those in "soft" disciplines (e.g., humanities, social sciences, education, etc.). Schuerholz-Lehr (2007) found that instructors in hard disciplines were more likely than those in soft disciplines to use a teacher-focused approach. Other researchers have identified that instructors in soft disciplines are more likely than those in hard disciplines to use deep approaches to learning (i.e., emphasize higher-order, integrative, and reflective learning; Nelson Laird, Shoup, Kuh, \& Schwarz, 2008) and include diverse course content and focus on inclusive learning strategies (Nelson Laird, 2011). However, faculty members in hard disciplines are more likely to emphasize peer learning than their soft discipline peers (Garver, Haywood, Ribera, \& Nelson Laird, 2009). These disciplinary differences may be a result of the ways in which faculty members' academic training and the culture of their disciplines affect their pedagogy (Lattuca \& Stark, 1994).

\section{The Present Study}

With the rise in short-term faculty-led student abroad programs (Gutiérrez et al., 2009; IIE, 2015; Obst et al., 2007), having faculty members serve as cultural mentors becomes an important factor in effectively facilitating students' intercultural development (Chieffo \& Griffiths, 2009). While current research has shown cultural mentoring as an important component of the intercultural development process for students on study abroad experiences, more research needs to be conducted to determine if and how faculty members teaching study abroad courses are taking on the role of cultural mentor. The purpose of this study is to: (a) describe how faculty members approach cultural mentoring while teaching short-term study abroad courses and (b) identify differences in the extent to which different faculty members engage in cultural mentoring based on their gender, academic rank, race, discipline, or intercultural competence.

\section{Methods}

Data for this study were collected via an online survey instrument created by the researchers. The survey was administered to faculty members/instructors who had taught short-term (eight weeks or less) study abroad courses over the past year. Directors of study abroad offices were contacted and asked to forward the survey link to faculty members who met the criteria for inclusion. The survey asked participants to answer questions based on their most recent short-term study abroad experience. The sample consisted of 473 faculty members from 72 colleges and universities. Sample demographics including gender, race, rank, and discipline can be found in Table 1. The overall response rate to the survey was approximately $16 \%$. 
Table 1. Sample Demographics and Frequency Distribution of Predictor Variables

\begin{tabular}{|c|c|c|}
\hline Variable & & Percentage \\
\hline \multirow[t]{2}{*}{ Race } & White & $86.4 \%$ \\
\hline & Faculty of Color & $13.6 \%$ \\
\hline \multirow[t]{2}{*}{ Gender Identity } & Female & $52.6 \%$ \\
\hline & Male & $47.4 \%$ \\
\hline \multirow[t]{2}{*}{ Birthplace } & U.S. & $50.4 \%$ \\
\hline & Non-U.S. & $49.6 \%$ \\
\hline \multirow[t]{9}{*}{ Discipline } & STEM & $18.9 \%$ \\
\hline & Other & $6.6 \%$ \\
\hline & Area Studies and Foreign Language & $10.7 \%$ \\
\hline & Business & $7.7 \%$ \\
\hline & Journalism and Communications & $5.2 \%$ \\
\hline & Education & $8.8 \%$ \\
\hline & Health Professions & $6.8 \%$ \\
\hline & General Humanities & $19.5 \%$ \\
\hline & Social Sciences & $5.9 \%$ \\
\hline \multirow[t]{4}{*}{ Rank } & Full Professor & $28.7 \%$ \\
\hline & Associate Professor & $29.9 \%$ \\
\hline & Assistant Professor & $27.0 \%$ \\
\hline & Non-Tenure Track & $27.0 \%$ \\
\hline \multirow[t]{2}{*}{ Language Ability } & One Language & $39.6 \%$ \\
\hline & More than One Language & $60.4 \%$ \\
\hline \multirow[t]{6}{*}{ Prior International Travel } & None & $0.5 \%$ \\
\hline & One Time & $0 \%$ \\
\hline & Two Times & $1.6 \%$ \\
\hline & Three Times & $1.6 \%$ \\
\hline & Four Times & $4.6 \%$ \\
\hline & Five or More Times & $91.6 \%$ \\
\hline Prior Experience Teaching & First Time & $19.3 \%$ \\
\hline \multirow[t]{4}{*}{ Study Abroad } & Second Time & $11.9 \%$ \\
\hline & Third Time & $10.1 \%$ \\
\hline & Fourth Time & $10.1 \%$ \\
\hline & Fifth Time or More & $48.3 \%$ \\
\hline
\end{tabular}

\section{Variables}

Cultural mentoring behaviors. On the survey, participants were asked to identify how frequently they engaged in a series of 31 different activities with students enrolled in their courses during their time abroad. Each activity was chosen for inclusion based on the conceptual and empirical literature on cultural mentoring described above (e.g., Paige \& Goode, 2009). Respondents could choose from a set of five responses where $1=$ "Never," $2=$ "Infrequently," $3=$ "Occasionally," $4=$ "Often," and $5=$ "Very Often."

Predictors of cultural mentoring. The independent variables for this study are the factors identified in related literature (e.g., Garver et al., 2009; Lattuca \& Stark, 1994; Mayhew \& Grunwald, 2006; Nelson Laird, 2011; Nelson Laird et al., 2008; Nelson Laird et al., 2011; Paige \& Goode, 2009; Schuerholz-Lehr, 2007) that may predict faculty engagement in cultural mentoring behaviors. Based on this literature, we included participants' gender, academic rank, race, and discipline, and three proxy measures for participants' own intercultural competence: language ability, prior international 
travel experience, and prior experience teaching study abroad courses. Gender identity was measured by a dichotomous variable $(0=$ female, $1=$ male $)$. Academic rank was measured by asking participants to indicate their primary appointment type (faculty or staff); those who selected "faculty" were then asked to choose their rank from a list of options (see Table 1). The group defined as Associate Professors served as the referent group to which other ranks were compared.

Racial identity was measured using a dichotomized item for the regression analysis $(0=W$ hite, $1=$ Faculty of Color). Participants were also grouped by their primary discipline, represented by STEM, Area Studies and Foreign Languages, Journalism and Communications, Business, Health Professions, General Humanities (other than area studies and foreign language), Education, Social Sciences, and Other, STEM served as the referent group in the analysis.

As we did not have a direct measure of participants' intercultural competence at the time they taught the study abroad course, we used participants' language ability, prior international travel experience, and prior experience teaching study abroad courses as proxies for intercultural competence. Olson and Kroeger (2001) found faculty members with high intercultural competence were seven times more likely to speak one or more languages with advanced proficiency and twice as likely to have spent substantive time abroad than those faculty members with lower intercultural competence.

Language ability was a dichotomous variable representing only one language $(0)$ and more than one language (1). Prior travel experience was measured with a variable representing the total number of times participants had traveled outside of the United States $(0=$ no prior travel, $1=1$ time, $2=2$ times, 3=3times, $4=4$ times, $5=$ five or more times). Similarly, prior study abroad teaching experience was measured with one variable indicating the total number of study abroad courses participants previously had taught $(1=$ first time teaching study abroad, 2=second time, $3=$ third time, $4=$ fourth time, $5=$ fifth time or more).

\section{Data Analysis}

Our first goal was to identify the ways in which faculty members engage in cultural mentoring while teaching short-term study abroad courses. To do this, we used exploratory factor analysis (EFA) in SPSS 23 and then modeled the factor structure using confirmatory factor analyses (CFA) with Mplus 7.11. Next, we employed multiple linear regression to predict the frequency with which faculty members engaged in cultural mentoring overall and in four different types of cultural mentoring identified in the factor analysis (for a total of five regression analyses). We employed single-level models with robust standard errors to account for the nesting of the data (faculty members within institutions), and full-information maximum likelihood estimation to handle missing data.

\section{Results}

Through the EFA and CFA analyses we identified five different factors, or types of cultural mentoring behaviors in which faculty members engage while teaching short-term study abroad courses: Facilitating Reflection, Expectation Setting, Explaining the Host Culture, Exploring Self in Culture, and Facilitating Connections. Interestingly, the Reflection factor showed only a moderate correlation with the other three factors (.567 to .651), whereas other factors had correlations ranging 
from .741 to .890 . Because participants seemed to engage in Reflection activities differently than other types of cultural mentoring behaviors, we excluded this factor to focus on what appeared to be core cultural mentoring behaviors.

Table 2. Standardized Loadings of 4-Factor Model of Cultural Mentoring

\begin{tabular}{|c|c|c|c|}
\hline \multicolumn{2}{|l|}{ Variable } & \multirow[t]{2}{*}{$\begin{array}{l}\text { Factor } \\
\text { Loading }\end{array}$} & $\mathbf{R}^{2}$ \\
\hline \multicolumn{3}{|c|}{ Expectation Setting $(\alpha=.870)$} & \\
\hline Q24_6 & Discuss students' overall expectations for the study abroad experience. & 0.814 & 0.662 \\
\hline Q24_7 & Discuss students' expectations of the host culture. & 0.907 & 0.823 \\
\hline Q24_8 & Discuss students' expectations of themselves in the host culture. & 0.784 & 0.614 \\
\hline \multicolumn{4}{|c|}{ Explaining the Host Culture $(\alpha=.812)$} \\
\hline Q24_1 & Discuss cultural differences between the U.S. and the host country. & 0.706 & 0.499 \\
\hline Q24_17 & Discuss specific aspects of the host culture that students are likely to encounter/observe. & 0.841 & 0.708 \\
\hline Q24_21 & Explain aspects of the host culture that students encounter/observe in country. & 0.755 & 0.570 \\
\hline \multicolumn{4}{|c|}{ Exploring Self in Culture $(\alpha=.912)$} \\
\hline Q24_9 & Discuss similarities and differences between students' expectations and experiences. & 0.696 & 0.484 \\
\hline Q24_10 & Discuss how students as a group were being perceived by the host culture. & 0.741 & 0.549 \\
\hline Q24_11 & $\begin{array}{l}\text { Discuss how individuals from the host culture reacted to students' appearance, skin color, } \\
\text { gender, sexual orientation, (dis)ability, etc. }\end{array}$ & 0.748 & 0.559 \\
\hline Q24_12 & Provide advice about navigating cultural issues in the host culture. & 0.773 & 0.597 \\
\hline Q24_15 & Discuss students' own cultural background. & 0.772 & 0.595 \\
\hline Q24_16 & Discuss the definition of culture. & 0.729 & 0.531 \\
\hline Q24_18 & Discuss the process of adapting to a different culture. & 0.832 & 0.692 \\
\hline Q24_31 & Discuss intercultural competence. & 0.752 & 0.566 \\
\hline \multicolumn{4}{|c|}{ Facilitate Connections $(\alpha=.825)$} \\
\hline Q24_22 & Discuss students' prior knowledge related to their experiences in-country. & 0.871 & 0.758 \\
\hline Q24_23 & $\begin{array}{l}\text { Help students make connections between their prior experiences and their experiences in- } \\
\text { country. }\end{array}$ & 0.833 & 0.694 \\
\hline Q24_27 & Help students compare and contrast different in-country experiences. & 0.662 & 0.438 \\
\hline \multicolumn{4}{|c|}{ Correlations } \\
\hline \multicolumn{4}{|c|}{ Host Culture with } \\
\hline & Expect & 0.719 & \\
\hline \multicolumn{4}{|c|}{ Self in Culture with } \\
\hline & Expect & 0.813 & \\
\hline & Host Culture & 0.886 & \\
\hline \multicolumn{4}{|c|}{ Connect with } \\
\hline & Expect & 0.754 & \\
\hline & Host Culture & 0.758 & \\
\hline & Self in Culture & 0.813 & \\
\hline \multicolumn{4}{|c|}{ Q24_11 with } \\
\hline & Q24_10 & 0.304 & \\
\hline
\end{tabular}

A model with the four correlated factors (Expectation Setting, Explaining the Host Culture, Exploring Self in Culture, and Facilitating Connections) did not quite reach "good" model fit $\left(\chi^{2}(112)=389.766, p<.001, R M S E A=.076, C F I=.928, S R M R=.047 ;\right.$ Hu \& Bentler, 1999). The specific items in each factor, along with item loadings and $R^{2}$ statistics can be found in Table 2. Because the high correlations between the four factors suggest a higher-order factor of Cultural Mentoring with four lower-order factors, the factor loadings from this implied higher-order CFA are 
reported in Table 3. From this analysis, we concluded that faculty generally have an overall approach to cultural mentoring, reflected in the higher-order Cultural Mentoring factor, but that there are different types of behaviors that constitute cultural mentoring (Expectation Setting, Explaining the Host Culture, Exploring Self in Culture, and Facilitating Connections).

\begin{tabular}{lll}
\multicolumn{3}{l}{ Table 3. Standardized Loadings of Higher-Order Cultu } \\
Factor & Factor Loading & $\mathbf{R}^{\mathbf{2}}$ \\
\hline Cultural Mentoring by & & \\
Expectation Setting & .834 & .711 \\
Explaining the Host Culture & .899 & .808 \\
Exploring Self in Culture & .966 & .933 \\
Facilitating Connections & .851 & .724 \\
\hline
\end{tabular}

Next, we turned to linear regression to examine whether there were differences in cultural mentoring behaviors based on faculty members' gender, academic rank, race, discipline, and/or intercultural competence. A summary of the significant findings across all five regression analyses can be found in Table 4. The predictors in the regression model explained $22.1 \%$ of the variance in overall Cultural Mentoring, $17.0 \%$ in Expectation Setting, $22.7 \%$ in Explaining the Host Culture, $22.5 \%$ in Exploring Self in Culture, and $14.5 \%$ in Facilitating Connections. Race, rank, and gender were all significant demographic predictors of at least one type of cultural mentoring. Faculty of Color engaged in more overall Cultural Mentoring, Expectation Setting, Explaining the Host Culture, and Exploring Self in Culture than did White faculty. Assistant professors engaged in significantly more than did associate professors. Male faculty engaged in significantly less Facilitating Connections than did female faculty.

Faculty members' own intercultural competence was generally not a significant predictor of any type of cultural mentoring, at least as measured by their language ability and prior international experience. Prior international travel experience was a significant, negative predictor of Expectation Setting and Exploring Self in Culture, but there were no other significant predictors of any of the five outcomes in this category. 
Elizabeth Niehaus et al.

Table 4. Regression Results

\begin{tabular}{|c|c|c|c|c|c|c|c|c|c|c|}
\hline \multirow[t]{2}{*}{$\begin{array}{l}\text { Predictor } \\
\text { Demographics } \\
\end{array}$} & \multicolumn{2}{|c|}{$\begin{array}{l}\text { Higher Order } \\
\text { Cultural } \\
\text { Mentoring } \\
\text { Factor }\end{array}$} & \multicolumn{2}{|c|}{$\begin{array}{l}\text { Expectation } \\
\text { Setting }\end{array}$} & \multicolumn{2}{|c|}{$\begin{array}{l}\text { Explaining the } \\
\text { Host Culture }\end{array}$} & \multicolumn{2}{|c|}{$\begin{array}{l}\text { Exploring } \\
\text { Self in } \\
\text { Culture }\end{array}$} & \multicolumn{2}{|c|}{$\begin{array}{l}\text { Facilitating } \\
\text { Connections }\end{array}$} \\
\hline & & & & & & & & & & \\
\hline Assistant & 0.154 & $*$ & 0.159 & $*$ & 0.074 & & 0.151 & $*$ & 0.165 & $*$ \\
\hline Full & 0.063 & & 0.069 & & 0.010 & & 0.081 & & -0.009 & \\
\hline $\begin{array}{l}\text { Non-Tenure } \\
\text { Track }\end{array}$ & 0.042 & & 0.092 & & -0.067 & & 0.057 & & 0.027 & \\
\hline Non-US Birth & -0.040 & & -0.084 & & 0.001 & & -0.042 & & -0.019 & \\
\hline Male & -0.044 & & 0.007 & & -0.074 & & -0.030 & & -0.097 & $*$ \\
\hline Faculty Of Color & 0.199 & $* *$ & 0.223 & $* * *$ & 0.124 & $*$ & 0.210 & $* * *$ & 0.099 & \\
\hline \multicolumn{11}{|l|}{$\underline{\text { Discipline }}^{\boldsymbol{\Delta}}$} \\
\hline $\begin{array}{l}\text { Area Studies and } \\
\text { Foreign } \\
\text { Language }\end{array}$ & 0.302 & $* * *$ & 0.234 & $* *$ & 0.370 & $* * *$ & 0.293 & $* * *$ & 0.142 & $*$ \\
\hline $\begin{array}{l}\text { Journalism and } \\
\text { Communications }\end{array}$ & 0.298 & $* * *$ & 0.220 & $* * *$ & 0.239 & $* * *$ & 0.322 & $* * *$ & 0.210 & $* * *$ \\
\hline Business & 0.159 & & 0.081 & & 0.179 & $*$ & 0.159 & $*$ & 0.125 & \\
\hline $\begin{array}{l}\text { Health } \\
\text { Professions }\end{array}$ & 0.156 & $*$ & 0.137 & $*$ & 0.161 & & 0.152 & $*$ & 0.086 & \\
\hline $\begin{array}{l}\text { General } \\
\text { Humanities }\end{array}$ & 0.332 & $* * *$ & 0.249 & $* *$ & 0.362 & $* * *$ & 0.341 & $* * *$ & 0.168 & $*$ \\
\hline Education & 0.260 & $* * *$ & 0.196 & $*$ & 0.239 & $* *$ & 0.267 & $* * *$ & 0.193 & $* *$ \\
\hline Social Sciences & 0.283 & $* * *$ & 0.232 & $* *$ & 0.291 & $* * *$ & 0.276 & $* * *$ & 0.193 & $* *$ \\
\hline $\begin{array}{l}\text { Other } \\
\text { Disciplines }\end{array}$ & 0.130 & $*$ & 0.054 & & 0.207 & $* * *$ & 0.126 & $*$ & 0.054 & \\
\hline
\end{tabular}

\section{Intercultural Competence}

$\underline{\text { Proxies }}$

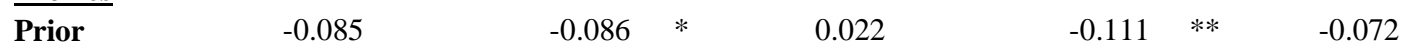

International

Travel

\begin{tabular}{llllll}
\hline $\begin{array}{l}\text { Prior Experience } \\
\text { Teaching Study } \\
\text { Abroad }\end{array}$ & 0.055 & 0.035 & 0.016 & 0.080 & 0.019 \\
\hline $\begin{array}{l}\text { Multiple } \\
\text { Languages }\end{array}$ & 0.037 & -0.006 & 0.099 & 0.012 & 0.092 \\
\hline $\mathbf{R}^{2}$ & 0.221 & 0.170 & 0.227 & 0.225 & 0.145 \\
\hline
\end{tabular}

NOTES: Standardized betas; $* p<.05, * * p<.01, * * * p<.001 ;{ }^{\mathbf{\Lambda}}$ Compared to faculty members in STEM disciplines

There were a number of significant disciplinary differences when it came to all five types of cultural mentoring. There were significant differences between STEM faculty members and faculty members in all other disciplines when it came to at least some aspect their engagement in cultural mentoring. Faculty members in Area Studies and Foreign Languages, Journalism and 
Communication, General Humanities, Education, and Social Sciences all engaged in significantly more cultural mentoring across all five outcomes than did faculty members in STEM (see Table 4). Faculty members in Business engaged in significantly more Explaining the Host Culture and Exploring Self in Culture than did STEM faculty members. Faculty members in Health Professions engaged in significantly more overall Cultural Mentoring, Expectation Setting, and Exploring Self in Culture; and faculty members in Other disciplines engaged in significantly more overall Cultural Mentoring, Explaining the Host Culture and Exploring Self in Culture than did STEM faculty members.

\section{Discussion}

Cultural mentoring is a key pedagogical practice faculty members teaching short-term study abroad courses can use to maximize students' intercultural competence development (Lou \& Bosley, 2012; Vande Berg et al., 2009). Our findings extend the current theoretical work on cultural mentoring by providing empirical evidence of how faculty members teaching short-term study abroad courses approach cultural mentoring. In our analyses, we identified four core types of interrelated cultural mentoring behaviors that align with the theoretical literature on cultural mentoring (e.g., Paige \& Goode, 2009): helping students set expectations for their study abroad experience, explaining aspects of the host culture to students, helping students explore their own selves in relation to the host culture, and facilitating connections between and among different experiences students are having before and during their study abroad experience. Although these four types of behavior are distinct, our analyses showed faculty members in our study generally approached these in the same way while teaching their study abroad courses.

It is not surprising that these types of behaviors form the core of how faculty members approach cultural mentoring. The purpose of cultural mentoring is to provide a cultural guide (Marx \& Moss, 2011) for students as they navigate the sometimes challenging process of learning about and adapting to a different cultural environment and helping students understand the host culture and their experiences within it are naturally key pieces of cultural mentoring. Helping students manage their expectations for their study abroad experience can also be a key part of providing support for students to have a positive learning experience.

Although the theoretical literature points specifically to the importance of providing opportunities for students to discuss their experiences with others, along with assisting students with the logistics of international travel and providing a "break" from the intensity of cross-cultural interactions (Paige \& Goode, 2009), we found that faculty members in our study did not necessarily approach these behaviors in the same way as they did the core cultural mentoring behaviors identified above. This does not mean these behaviors are not important, or that they should not be considered part of cultural mentoring, but it is important to note that faculty members may think about and approach these behaviors differently than they do behaviors related to explaining and exploring culture, setting expectations, and facilitating connections.

We found a number of key predictors of the extent to which faculty members will engage in cultural mentoring while teaching short-term study abroad courses. Academic rank, race, and discipline were fairly consistent predictors of cultural mentoring behaviors. While previous studies have found no differences in the status and rank of faculty in incorporating peer learning (Garver et 
al., 2009) or tenure and time at the institution for incorporating diversity-related content into their pedagogy (Mayhew \& Grunwald, 2006), our study found that Assistant Professors engaged in significantly more cultural mentoring than did Associate Professors, overall and across three of the four different types of cultural mentoring (all except for Explaining the Host Culture). Faculty of Color engaged in significantly more cultural mentoring than did White faculty, overall and across three of the four types (all except for Facilitating Connections). These results mirror those of previous studies that found that Faculty of Color are more likely than their White counterparts to incorporate diversity-related content (Mayhew \& Grunwald, 2006) and diverse perspectives (Nelson Laird et al., 2008) into their courses. Consistent with other studies that have found that faculty in hard disciplines emphasize diversity inclusivity (Nelson Laird, 2011) and deeper approaches to learning (Nelson Laird et al., 2008) less than faculty in soft disciplines, our study found that STEM faculty consistently engaged in less cultural mentoring than did faculty in most other disciplines, especially Area Studies and Foreign Language, Journalism and Communications, General Humanities, Education, and Social Sciences.

\section{Conclusion and Implications}

This study examined the ways in which faculty members engage in cultural mentoring during short-term study aboard courses. The results identified four core types of interrelated cultural mentoring behaviors, including helping students set expectations for their study abroad experience, explaining aspects of the host culture to students, helping students explore their own selves in relation to the host culture, and facilitating connections between and among different experiences students are having before and during their study abroad experience. These findings have implications for research and practice.

In identifying different types of cultural mentoring behaviors, the results of this study can help education abroad professionals think about how to structure training and support for faculty members around issues of cultural mentoring. The findings related to predictors of cultural mentoring behaviors can provide further guidance for practitioners looking to target faculty training efforts. For instance, the rising number of STEM students studying abroad (IIE, 2015) paired with the findings from this study that STEM faculty members are less likely than others to engage in cultural mentoring points to a need to provide cultural mentoring training for this group of faculty members. As disciplinary cultures can have a strong effect on how faculty members approach teaching (Lattuca \& Stark, 1994), education abroad professionals may want to consider partnering with discipline-based faculty members to better target training toward faculty members in different disciplines.

Despite the value of these findings for building theory around cultural mentoring and guiding practice in education abroad, there are a number of limitations to this study that point to directions for future research in this area. First, this study is an initial exploration of cultural mentoring behaviors, using items written specifically for this study; additional research is needed to further refine the items and cultural mentoring constructs identified in this study. In particular, our final measurement model did not quite achieve good model fit. Although the results still provide a valuable perspective on cultural mentoring in short-term study abroad courses, more work should be done to improve the measurement of these constructs. 
Second, the fact that behaviors such as assisting with travel logistics and providing a break from cultural immersion were not closely related to the core cultural mentoring behaviors we identified deserves further study. It is possible that differently worded items related to these behaviors might better capture their relationship to cultural mentoring; future research might also confirm the finding that these are separate pedagogical behaviors. Similarly, it was surprising that items related to facilitating reflection (e.g., providing opportunities for students to discuss their experiences with one another) were not part of this set of cultural mentoring behaviors. It is possible the items related to facilitating connections actually point to a specific type of reflection that may be an important part of how faculty members approach cultural mentoring - helping students think more deeply about the experiences they are having, rather than simply providing opportunities for students to discuss their experiences with one another. Since activities related to reflection are often seen as a hallmark of study abroad experiences, further study of reflection in the context of short-term study abroad courses is necessary to understand the role a faculty member plays with respect to reflection before, during, and after the study abroad experience.

Finally, our study only identified what faculty members are doing in teaching study abroad courses, not the effect this has on students' learning and intercultural development. Although prior research has identified a connection between cultural mentoring and student learning (e.g., Lou \& Bosley, 2012; Vande Berg et al., 2009), further research is needed to examine which types of cultural mentoring behaviors best facilitate student learning under which conditions. This study is an important first step in exploring how to measure cultural mentoring behaviors best, but more research is needed to put cultural mentoring into the broader context of assessing the relationship between pedagogical practices and student outcomes in short-term study abroad.

\section{References}

Allport, G. W. (1954). The nature of prejudice. Reading, MA: Addison-Wesley Publishing Company.

Association of American Colleges and Universities [AACU]. (2011). The LEAP vision for learning:

Outcomes, practices, impact, and employers' views. Washington, DC: Author. Retrieved from https://www.aacu.org/publications-research/publications/leap-vision-learning-outcomes-practicesimpact-and-employers

Anderson, P. H., Lawton, L., Rexeisen, R.J., \& Hubbard, A.C. (2006). Short term study abroad and intercultural sensitivity: A pilot study. International Journal of Intercultural Relations, 30, 457-469.

Bennet, J. M. (2008). On becoming a global soul: A path to engagement during study abroad. In V. Savicki (Ed.), Developing intercultural competence and transformation: Theory, research, and application in international education (pp.32-52). Sterling, VA: Stylus.

Buffington, H. (2014). The experience of students on site. In M. Hernandez, M. Wiedenhoeft, \& D. Wick (Eds.), NAFSA's guide to education abroad for advisers and administrators. $4^{\text {th }}$ ed. (pp.227-241). Washington D. C.: NAFSA.

Chieffo, L., \& Griffiths, L. (2009). Here to stay: Increasing acceptance of short-term study abroad programs. In R. Lewin (Ed.), The handbook of practice and research in study abroad: Higher education and the quest for global citizenship (pp.365-380). New York: Routledge Taylor and Francis Group.

Chieffo, L., \& Griffiths, L. (2004). Large-scale assessment of student attitudes after a short-term study abroad program. Frontiers: The International Journal of Study Abroad, 10, 165-177.

Commission on the Abraham Lincoln Study Abroad Fellowship. (2005). Global competencies and national needs: One million Americans studying abroad. Retrieved from http://www.nafsa.org/_/Document/_lincoln_commission_report.pdf 
Doyle, S., Gendall, P., Meyer, L. H., Hoek, J. Tait, C. McKenzie, L, \& Loorparg, A. (2010). An investigation of factors associated with student participation in study abroad. Journal of Studies in International Education, 14(5), 471-490.

Garver, A. K., Haywood, A., Ribera, T., \& Nelson Laird, T. F. (2009, November). Peer learning: Understanding faculty and course characteristics. Paper presented at the annual meeting of the Association for the Study of Higher Education, Vancouver, British Columbia, Canada.

Goode, M. L. (2008). The role of faculty study abroad directors: A case study. Frontiers: The Interdisciplinary Journal of Study Abroad, 15, 149-172.

Gutiérrez, R., Auerbach, J, \& Bhandar, R. (2009). Expanding U.S. study abroad capacity: Findings from an IEE-forum survey. In P. Blumenthal \& R. Gutierrez (Eds.), Expanding study abroad capacity at U.S. colleges and universities. Institute of International Education Study Abroad White Paper Series, 6. New York, NY: Institute of International Education.

Hu, L. \& Bentler, P. (1999). Cutoff criteria for fit indices in covariance structure analysis: conventional criteria versus new alternatives. Structural Equation Modeling, 6, 1-55.

Institute of International Education. (2015). Open doors report on international educational exchange. Retrieved from http://www.iie.org/opendoors

Institute of International Education. (2014). What will it take to double study abroad? Retrieved from http://www.iie.org/Research-and-Publications/Publications-and-Reports/IIE-Bookstore/What-Will-ItTake-To-Double-Study-Abroad

Jackson, J. (2008). Globalization, internationalization, and short-term stays abroad. International Journal of Intercultural Relations, 32, 349-358.

Keese, J. R., \& O’Brien, J. (2011). Learn by going: Critical issues for faculty-led study-abroad programs.

The California Geographer, 51,91-113.

Kehl, K., \& Morris, J. (2007). Differences in global-mindedness between short-term and semester-long study abroad participants at selected private universities. Frontiers: The Interdisciplinary Journal of Study Abroad, 15, 67-79.

Koskinen, L., \& Tossavainen, K. (2004). Study abroad as a process of learning intercultural competence in nursing. International Journal of Nursing Practice, 10(3), 111-120.

Lattuca, L. R., \& Stark, J. S. (1994). Will disciplinary perspectives impede curricular reform? The Journal of Higher Education, 65(4), 401-426.

Lou, K. H., \& Bosley, G. W. (2012). Facilitating intercultural learning abroad: The intentional, targeted intervention model. In M. Vande Berg, R. M. Paige, \& K. H. Lou (Eds.), Student learning abroad: What our students are learning, what they're not, and what we can do about it (pp. 29-58). Sterling, VA: Stylus.

Lucas, J. (2009). Over-stressed, overwhelmed, and over here: Resident directors and the challenges of student mental health abroad. Frontiers: The Interdisciplinary Journal of Study Abroad, 18, 187-215.

Marx, H., \& Moss, D. M. (2011). Please mind the gap: Intercultural development during a teacher education study abroad program. Journal of Teacher Education, 2(1), 35-47.

Mayhew, M. J., \& Grunwald, H. E. (2006). Factors contributing to faculty incorporation of diversityrelated course content. Journal of Higher Education, 77(1), 148-168.

Medina-López-Portillo, A. (2004). Intercultural learning assessment: The link between program duration and the development of intercultural sensitivity. Frontiers: The Interdisciplinary Journal of Study Abroad, 10, 179-199.

Nelson Laird, T. (2011). Measuring the diversity inclusivity of college courses. Research in Higher Education, 52(6), 572-588.

Nelson Laird, T. F., Garver, A. K., \& Niskodé-Dossett, A. S. (2011). Gender gaps in collegiate teaching style: Variations by course characteristics. Research in Higher Education, 52(3), 261-277.

Nelson Laird, T. F., Shoup, R., Kuh, G. D., \& Schwarz, M. J. (2008). The effects of discipline on deep approaches to student learning and college outcomes. Research in Higher Education, 49, 469-494. 
Obst, D., Bhandari, R., \& Witherell, S. (2007, May). Current trends in U.S. study abroad \& the impact of strategic diversity initiatives. Institute of International Education Study Abroad White Paper Series, 1. New York, NY: Institute of International Education.

Olson, C. L., \& Kroeger, K. R. (2001). Global competency and intercultural sensitivity. Journal of Studies in International Education, 5(2), 116-137.

Paige, R. M., \& Goode, M. (2009). Intercultural competence in international education administration: Cultural mentoring. In D. K. Deardorff (Ed.), The SAGE handbook of intercultural competence (pp. 121-140). Thousand Oaks, CA: Sage.

Paige, R. M., \& Vande Berg, M. (2012). Why students are and are not learning abroad: A review of the recent research. In M. Vande Berg, R. M. Paige, \& K. H. Lou (Eds.), Student learning abroad: What our students are learning, what they're not, and what we can do about it (pp. 29-58). Sterling, VA: Stylus.

Pettigrew, T. F., \& Tropp, L. R. (2005). Allport's intergroup contact hypothesis: Its history and influence. In J. Dovidio, P. Glick, \& L. Rudman (Eds.), On the nature of prejudice: Fifty years after Allport (pp. 262-277). Malden, MA: Blackwell Publishing.

Schuerholz-Lehr, S. (2007). Teaching for global literacy in higher education: How prepared are the educators? Journal of Studies in International Education, 11(2), 180-204. doi: $10.1177 / 1028315307299419$

Stier, J. (2003). Internationalisation, ethnic diversity and the acquisition of intercultural competencies. Intercultural Education, 14(1), 77-91.

Vande Berg, M., Connor-Linton, J., \& Paige, R. M. (2009). The Georgetown Consortium Project: Interventions for study learning abroad. Frontiers: The Interdisciplinary Journal of Study Abroad, $18,1-75$.

Vande Berg, M., Paige, R. M., \& Lou, K. H. (2012). Student learning abroad: Paradigms and assumptions. In M. Vande Berg, R. M. Paige, \& K. H. Lou (Eds.), Student learning abroad: What our students are learning, what they're not, and what we can do about it (pp. 3-28). Sterling, VA: Stylus. 